\title{
PERSEPSI MAHASISWA AKUNTANSI TERHADAP ETIKA PENYUSUNAN LAPORAN KEUANGAN SYARI'AH SESUAI PSAK No. 101
}

\author{
Wasilaturahmi Siregar \\ Khusnul Hidayah
}

\begin{abstract}
This research to determine differences in accounting students perceptions of the ethics financial shari'ah statement in accordance with SFAS No. 101. The analysis was based on respondents answers were obtained through questionnaires distributed at Private Colleges and Universities Public Islam. Population of this study is that accounting students are in Private Colleges and Universities Public Islam. This study uses purposive sampling method. Samples were taken from six semesters of accounting students and eight who have taken courses Accounting Theory. To test the validity of the data used Pearson correlation, to test the reliability of the data used Cronbach Alpha while the data used to test the normality Kolmogorov-Smirnov, and the data used to test for differences Independent samples t-test. The results are hypothesis 1, hypothesis 2, hypothesis 4, and 5 are acceptable hypothesis that there are differences in the perception of earnings management, misstatements in the financial statements, cost-benefit, and responsibility to the users of financial statements Shariah between accounting students at university Private Higher Islam and Higher Education General. And hypothesis 3 was rejected, ie there is no difference between the perceptions of disclosure of accounting students in Private Colleges and Universities Public Islam.
\end{abstract}

Keywords: student perceptions of accounting, the financial statements ethics Shari'ah.

\section{PEMBAHASAN}

Laporan keuangan syari'ah adalah suatu penyajian terstruktur dari posisi keuangan dan kinerja keuangan dari suatu entitas syari'ah (PSAK Nomor 101). Tujuan laporan keuangan untuk tujuan umum adalah memberikan informasi tentang posisi keuangan, kinerja dan arus kas entitas syari'ah yang bermanfaat bagi sebagian besar kalangan pengguna laporan dalam rangka membuat keputusankeputusan ekonomi serta menunjukkan pertanggungjawaban (stewardship) manajemen atas penggunaan sumber-sumber daya yang dipercayakan kepada mereka. Tujuan laporan keuangan akuntansi syari'ah, yaitu (Khan, 1992 dalam As'udi dan Triyuwono, 2003: 34). 
a. Penentuan laba-rugi yang tepat, kehati-hatian harus dilaksanakan dalam menyiapkan laporan keuangan agar dapat mencapai hasil yang sesuai dengan syari'ah, dan konsisten dalam pemilihan metoda yang digunakan sehingga dapat menjamin kepentingan semua pihak (pengguna laporan keuangan).

b. Meningkatkan dan menilai efisiensi kepemimpinan, sistem akuntansi harus mampu memberikan standar untuk menjamin bahwa manajemen mengikuti kebijakan-kebijakan yang sehat.

c. Ketaatan pada hukum syari'ah, setiap aktivitas yang yang dijalankan oleh entitas usaha harus dapat dinilai hukum halal-haramnya.

d. Keterikatan pada keadilan, dalam rangka mewujudkan tujuan utama dari syari'ah adalah menciptakan maslahah, dan keadilan adalah bagian yang terpenting dalam mencapai maslahah, maka penegakan keadilan adalah mutlak adanya.

e. Melaporkan dengan benar, entitas usaha selain bertanggungjawab terhadap pemilik juga harus bertanggungjawab kepada masyarakat secara keseluruhan, informasi harus berada dalam posisi yang terbaik untuk melaporkan hal ini.

f. Adaptable terhadap perubahan, peranan akuntansi yang sangat luas menuntut akuntansi agar peka terhadap tuntutan kebutuhan, agar akuntansi senantiasa dapat difungsikan oleh masyarakat sesuai tuntutan kebutuhannya.

Menurut Wyatt (2004) dalam Yulianti dan Fitriany (2005: 4) kelemahan yang terdapat pada akuntan adalah keserakahan individu dan korporosi, pemberi jasa yang mengurangi indenpendensi, sikap terlalu lunak pada klien dan peran serta dalam menghindari aturan akuntansi yang ada. Wyatt menambahkan bahwa untuk menghindari hal-hal tersebut, akuntan pendidik seharusnya memberikan perhatian yang lebih besar dalam pendidikan akuntansi atas dua hal, yaitu apresiasi terhadap profesi akuntan dan apresiasi mengenai dilema etika (ethical dilemmas). Oleh karena itu, peneliti tertarik melakukan penelitian mengenai persepsi mahasiswa akuntansi terhadap etika penyusunan laporan keuangan syari'ah sesuai PSAK No. 101. Peneliti bermaksud untuk melihat perilaku dan persepsi mahasiswa akuntansi menyangkut etika penyusunan laporan keuangan syari'ah untuk memenuhi 
kebutuhan pengguna laporan keuangan sebagai bentuk tanggung jawab mereka terhadap profesi akuntan.

\section{LANDASAN TEORI DAN PENGEMBANGAN HIPOTESIS}

\section{Persepsi}

Persepsi merupakan proses untuk memahami lingkungannya meliputi objek, orang, dan simbol, atau tanda yang melibatkan proses kognitif (pengenalan). Persepsi mencakup penerimaan, pengorganisasian, dan penafsiran stimulus yang telah diorganisasi dengan cara yang dapat mempengaruhi perilaku dan membentuk sikap. Menurut (Robbins 2002: 46) dalam Fitriani (2010:30) persepsi dipengaruhi oleh: sikap, kepribadian, motif, kepentingan, pengalaman masa lalu, dan harapan.

\section{Etika Penyusunan Laporan Keuangan Syari’ah}

Setiap profesi yang memberikan pelayanan jasa pada masyarakat harus memilki kode etik yang merupakan seperangkat prinsip-prinsip moral yang mengatur tentang perilaku profesional. Tanpa etika, profesi akuntan tidak akan ada karena fungsi akuntan adalah sebagai penyedia informasi untuk proses pembuatan keputusan bisnis oleh para pelaku bisnis (Agoes ,2004 dalam Herawaty dan Yulius Kurnia Susanto, 2009: 14). Etika profesi merupakan karakteristik suatu profesi yang membedakan suatu profesi dengan profesi lain, yang berfungsi untuk mengatur tingkah laku para anggotanya (Murtanto dan Martini, 2003). Etika penyusunan laporan keuangan syari'ah dalam penelitian ini adalah pada masalah manajemen laba, salah saji, pengungkapan informasi yang sensitif, cost-benefit pengungkapan informasi, dan tanggungjawab terhadap pengguna laporan keuangan.

\section{Manajemen Laba}

Manajemen laba merupakan upaya untuk menghasilkan laporan keuangan agar terlihat lebih baik yang bertujuan untuk menarik perhatian investor agar mereka bersedia untuk menanamkan modal kepada perusahaan, manajemen laba menarik untuk diteliti karena dapat memberikan gambaran tentang perilaku manajer dalam melaporkan kegiatan usahanya pada suatu periode tertentu. Suatu penelitian menunjukkan bahwa praktik manajemen laba yang dilakukan perusahaan- 
perusahaan yang menjadi sampel dalam penelitian ini mempunyai pengaruh negatif yang signifikan terhadap kinerja keuangan. Artinya pengaruh yang diakibatkan dari praktik manajemen laba memberikan dampak menurunnya kinerja keuangan perusahaan.

Mahasiswa akuntansi di Perguruan Tinggi Swasta Islam tidak setuju dengan adanya praktik manajemen laba karena substansi akuntansi syari'ah adalah pertanggungjawaban dan kebenaran (adil dan jujur). Sedangkan pada mahasiswa akuntansi di Perguruan Tinggi Umum, laba adalah merupakan sesuatu yang penting dan sangat dinilai tinggi hingga sangat dapat mempengaruhi pengguna laporan keuangan untuk menginvestasikan pada perusahaan. Berdasar uraian tersebut, maka hipotesis yang diperoleh adalah:

$\mathrm{H}_{1}$ : Terdapat perbedaan persepsi mengenai manajemen laba antara mahasiswa akuntansi di Perguruan Tinggi Swasta Islam dan Perguruan Tinggi Umum.

\section{Salah Saji dalam Laporan Keuangan}

Kesalahan pencatatan akuntansi dapat menyebabkan salah saji material pada pelaporan keuangan. Salah saji material pada pelaporan keuangan mengacu pada pengertian bahwa keputusan pengguna laporan keuangan akan terpengaruh/terkecoh oleh ketidakakuratan informasi yang terjadi karena salah saji tersebut. Kesalahan pencatatan akuntansi juga bisa dikategorikan menjadi 2, yaitu:

a. Kelalaian (error) mengacu pada kesalahan akuntansi yang dilakukan secara tidak sengaja diakibatkan oleh salah perhitungan, salah pengukuran, salah estimasi serta salah interpretasi standar akuntansi.

b. Kecurangan (fraud) mengacu kepada kesalahan akuntansi yang dilakukan secara sengaja dengan tujuan menyesatkan pembaca/pengguna laporan keuangan. Tindakan ini dilakukan dengan motivasi negatif guna mengambil keuntungan sebagian pihak.

Harahap (2001: 23) mengemukakan bahwa akuntansi syariah adalah suatu bentuk akuntansi yang disusun berdasarkan pada pencapaian tujuan syariah, tujuan ekonomi Islam, serta kemaslahatan masyarakat. Hal inilah yang diajarkan pada mahasiswa akuntansi di Perguruan Tinggi Swasta Islam, sedangkan pada mahasiswa akuntansi di Perguruan Tinggi Umum, nilai-nilai etika memang 
diajarkan tetapi tidak dilandasi dengan aturan syari'ah. Berdasar uraian tersebut, maka hipotesis yang diperoleh adalah:

$\mathrm{H}_{2}$ : Terdapat perbedaan persepsi mengenai salah saji dalam laporan keuangan dalam perusahaan antara mahasiswa akuntansi di Perguruan Tinggi Swasta Islam dan Perguruan Tinggi Umum.

\section{Pengungkapan Informasi}

Tujuan laporan keuangan adalah menyediakan informasi yang menyangkut posisi keuangan, kinerja, serta perubahan posisi keuangan suatu perusahaan yang bermanfaat bagi sejumlah besar pemakai dan pengambilan keputusan ekonomi. Menurut Harahap (2001; 31) tujuan utama dari laporan keuangan adalah memberikan informasi yang berguna untuk pengambilan keputusan ekonomis. Para pemakai laporan akan menggunakannya untuk meramalkan, membandingkan, dan menilai dampak keuangan yang timbul dari keputusan ekonomis yang diambilnya.

Informasi mengenai dampak keuangan yang timbul tadi sangat berguna bagi pemakai untuk meramalkan, membandingkan dan menilai arus kas. Seandainya nilai uang tidak stabil, maka hal ini akan dijelaskan dalam laporan keuangan. Laporan keuangan akan lebih bermanfaat apabila yang dilaporkan tidak saja aspekaspek kuantitatif, tetapi mencakup penjelasan-penjelasan lainnya yang dirasakan perlu. Informasi ini harus faktual dan dapat diukur secara objektif. Berdasar uraian tersebut, maka hipotesis yang diperoleh adalah:

$\mathrm{H}_{3}$ : Terdapat perbedaan persepsi mengenai pengungkapan informasi yang sensitif dalam perusahaan antara mahasiswa akuntansi di Perguruan Tinggi Swasta Islam dan Perguruan Tinggi Umum.

\section{Cost and Benefit Pengungkapan Informasi}

Secara konseptual, pengungkapan merupakan bagian yang integral dari pelaporan keuangan. Secara teknis, pengungkapan merupakan langkah akhir dalam proses akuntansi yaitu penyajian informasi dalam bentuk seperangkat penuh statemen keuangan. Secara umum, tujuan pengungkapan adalah menyajikan informasi yang dipandang perlu untuk mencapai tujuan pelaporan keuangan dan untuk melayani berbagai pihak yang mempunyai kepentingan berbeda-beda. 
Akuntansi syari'ah memandang bahwa kedua tujuan dasar dari akutansi yaitu memberikan informasi dan akuntabilitas dianggap sebagai suatu kesatuan yang tidak bisa dipisahkan satu sama lainnya dan inilah yang menjadikan perbedaan besar dengan tujuan dasar akutansi konvensional. Berdasar uraian tersebut, maka hipotesis yang diperoleh adalah:

$\mathrm{H}_{4}$ : Terdapat perbedaan persepsi mengenai cost-benefit pengungkapan informasi antara mahasiswa akuntansi di Perguruan Tinggi Swasta Islam dan Perguruan Tinggi Umum.

\section{Tanggung Jawab terhadap Penggunaan Laporan Keuangan}

Akuntansi syariah diperlukan oleh masyarakat Islam sebagai instrument pendukung menerapkan praktik ekonomi Islam dalam tata kehidupan sosialekonominya dengan dasar pertimbangan berikut (Yusoh dan Ismail, 2001 dalam Harahap, 2001). Adanya konsep kepemilikan yang diyakini oleh orang Islam bahwa harta dan kekayaan adalah milik Allah SWT, manusia hanyalah penerima amanah yang harus mempertanggungjawabkan pemanfaatannya sesuai dengan syariah. Adanya konsep personal accountability yang harus dipatuhi oleh Islam dalam menjalin hubungan dengan Allah SWT (hablum minallah) dan menjalin hubungan dengan sesama manusia (hablum minannas). Berdasar uraian tersebut, maka hipotesis yang diperoleh adalah:

$\mathrm{H}_{5}$ : Terdapat perbedaan persepsi mengenai tanggung jawab terhadap pengguna laporan keuangan antara mahasiswa akuntansi di Perguruan Tinggi Swasta Islam dan Perguruan Tinggi Umum.

\section{METODA PENELITIAN}

\section{Populasi dan Sampel}

Sampel dalam penelitian ini adalah mahasiswa akuntansi di Universitas Ahmad Dahlan, Universitas Muhammadiyah Yogyakarta, Universitas Pembangunan Nasional Veteran Yogyakarta, dan Universitas Sarjanawiyata Tamansiswa Yogyakarta semester enam dan semester delapan. Teknik pengambilan sampel pada penelitian ini menggunakan purposive sampling, yaitu teknik dengan 
pengambilan dengan kriteria responden. Kriteria responden dalam penelitian ini adalah sebagai berikut:

1. Mahasiswa akuntansi semester enam dan semester delapan.

2. Mahasiswa akuntansi yang sudah mengambil mata kuliah teori akuntansi, karena pada mata kuliah teori akuntansi mahasiswa sudah dijelaskan tentang laporan keuangan yang baik dan tentang aturan-aturan yang berlaku dalam akuntansi.

Penelitian bersifat behavioral (perilaku dan persepsi) karenanya data yang akan digunakan dalam penelitian ini adalah data primer. Data yang diperoleh berupa data ordinal dan jenisnya adalah cross section yaitu data yang diambil pada saat itu juga.

\section{Pengukuran Variabel}

Etika Penyusunan Laporan Keuangan Syari'ah diproksikan ke dalam 5 item yaitu manajemen laba, salah saji dalam laporan keuangan, pengungkapan informasi yang sensitif, cost-benefit pengungkapan informasi, tanggungjawab terhadap pengguna laporan keuangan. Masing-masing pertanyaan diukur dalam 5 item pernyataan dengan menggunakan skala Likert 1-5. Artinya adalah semakin tinggi skor maka nilainya pun akan semakin baik.

\section{ANALISIS DATA}

\section{Uji Validitas}

Pengujian validitas dilakukan dengan mengorelasikan setiap item pertanyaan dengan total nilai setiap variabel. Korelasi setiap pertanyaan dengan total nilai variabel dilakukan dengan uji korelasi Pearson, yaitu jika nilai signifikansi setiap pertanyaan < 0,05 maka dapat disimpulkan bahwa setiap butir pertanyaan dinyatakan valid (Ghozali, 2006).

\section{Uji Realibilitas}

Uji reliabilitas sebenarnya adalah alat untuk mengukur suatu kuesioner yang merupakan indikator dari variabel. Suatu kuesioner dinyatakan reliabel atau handal jika jawaban seseorang terhadap pertanyaan adalah konsisten atau stabil dari waktu 
ke waktu ( Ghozali, 2006). Jika koefisien Cronbach alpha > 0,60 maka konstruk variabel dikatakan reliabel begitu juga sebaliknya Jika nilai Cronbach alpha < 0,60 maka pertanyaan-pertanyaan yang digunakan untuk mengukur variabel tersebut adalah tidak reliabel.

\section{Uji Normalitas}

Uji normalitas data adalah alat analisis untuk mengetahui apakah suatu data berasal dari populasi yang sama. Untuk menguji normalitas data dilakukan dengan menggunakan teknik one sample Kolmogorov-Smirnov test, pengujian dua sisi yang dilakukan dengan membandingkan siginifikansi hasil uji ( $\mathrm{p}$ value) dengan taraf signifikansi. Dengan pedoman pengambilan keputusan yaitu jika nilai Asymp. Sig (2-tailed) $<0,05$ (alpha) maka data terdistribusi tidak normal, sampel di tarik bukan dari populasi dengan distribusi tertentu dan jika Asymp. Sig (2-tailed) $>0,05$ (alpha) maka data berdistribusi normal/sampel ditarik dari populasi dengan distribusi tertentu (Kurniawati, 2006).

\section{Uji Hipotesis}

Pengujian hipotesis beetujuan untuk menentukan jawaban teoritis yang terkandung dalam pernyataan hipotesis didukung oleh fakta yang dikumpulkan dan dianalisis dalam pemrosesan pengujian data. Penerimaan atau penolakan atas hipotesis tergantung dari hasil analisis data di lapangan. Jika hasil analisis data sesuai dengan teori berarti hipotesis tersebut dapat diterima, jadi apabila di lapangan hasil analisis mendukung pernyataan teori maka hipotesis yang ditarik dapat diterima.

Jika data berdistribusi normal maka hipotesis diuji dengan menggunakan independent sample t-test, dan dalam melakukan pengujian independent sample ttest terdapat 2 asumsi yang bisa dipilih yaitu asumsi kedua grup mempunyai varians yang sama dan varians yang berbeda, sehingga sebelum menguji menggunakan independent sample t-test harus dilakukan uji beda varians. Uji beda varian dilakukan dengan melihat nilai levene's tes for equality of variance. 
1) Jika nilai signifikansi $\mathrm{F}$ hitung $>0,05$ maka diasumsikan varians kedua grup adalah sama/identik, maka menggunakan dasar equal variance assumed (Ghozali 2006: 57).

2) Jika nilai signifikansi $\mathrm{F}$ hitung $<0,05$ maka diasumsikan varians kedua grup tidak sama/tidak identik maka, menggunakan dasar equal variance not assumed.

Setelah dilakukan uji beda varians, pengambilan keputusan menerima atau menolak hipotesis dengan menggunakan sample t-test dengan kriteria sebagai berikut:

1) Jika signifikansi t hitung $>0,05$ maka hipotesis ditolak

2) Jika signifikansi t hitung $<0,05$ maka hipotesis diterima

Menguji normalitas dalam penelitian ini menggunakan uji Kolmogorov Smirnov. Dasar pengambilan keputusan adalah jika probabilitas signifikannya di atas kepercayaan 5\% maka model regresi memenuhi asumsi normalitas (Ghozali, 2006). Sedangkan jika data berdistribusi tidak normal (non parametik) maka hipotesis diuji dengan menggunakan Mann Whitney. Uji Mann Whitney merupakan bagian dari statistik non parametik yang bertujuan untuk membantu peneliti didalam membedakan hasil kinerja kelompok yang terdapat dalam sampel ke dalam 2 kelompok dengan dua kriteria yang berbeda. Pengambilan keputusan menerima atau menolak hipotesis dengan menggunakan Mann Whitney yaitu dengan kriteria uji sebagai berikut:

1) Jika nilai signifikansi (2-tailed) $>0,05$ maka hipotesis ditolak

2) Jika nilai signifikansi (2-tailed $)<0,05$ maka hipotesis diterima. 
HASIL DAN PEMBAHASAN

Uji Validitas

Tabel 1

Hasil Uji Validitas

\begin{tabular}{|c|c|c|c|c|}
\hline Variabel & Item & Nilai Sig. & Alpha & Keterangan \\
\hline Manajemen Laba & ML & .000 & 0,05 & Valid \\
\hline \multirow{4}{*}{ Salah saji } & SJ1 & .000 & 0,05 & Valid \\
\cline { 2 - 5 } & SJ2 & .000 & 0.05 & Valid \\
\cline { 2 - 5 } & SJ3 & .000 & 0.05 & Valid \\
\hline Pengungkapan Informasi & P1 & .000 & 0.05 & Valid \\
\cline { 2 - 5 } & P2 & .000 & 0.05 & Valid \\
\cline { 2 - 5 } & P3 & .001 & 0.05 & Valid \\
\cline { 2 - 5 } & P4 & .000 & 0.05 & Valid \\
\cline { 2 - 5 } & P5 & .000 & 0.05 & Valid \\
\hline \multirow{7}{*}{ Cost Benefit } & CB1 & .000 & 0.05 & Valid \\
\cline { 2 - 5 } & CB2 & .000 & 0.05 & Valid \\
\hline Tanggungjawab & TJW1 & .000 & 0.05 & Valid \\
\cline { 2 - 5 } & TJW2 & .000 & 0.05 & Valid \\
\hline
\end{tabular}

Sumber: Data primer, diolah (2013).

Hasil dari pengujian validitas ini menyatakan bahwa seluruh item pertanyaan dalam instrument penelitian mempunyai nilai signifikansi $<0,05$ maka dapat disimpulkan bahwa seluruh item pertanyaan adalah valid.

\section{Uji Reliabilitas}

Tabel 2

Hasil Uji Reliabilitas

\begin{tabular}{|c|c|c|c|}
\hline Variabel & Item & Cronbach's Alpha & Keterangan \\
\hline Manajemen Laba & ML & 0,749 & Reliabel \\
\hline \multirow{3}{*}{ Salah Saji } & SJ1 & 0,764 & Reliabel \\
\cline { 2 - 4 } & SJ2 & 0,764 & Reliabel \\
\cline { 2 - 4 } & SJ3 & 0,756 & Reliabel \\
\hline Pengungkapan Informasi & P1 & 0,762 & Reliabel \\
\cline { 2 - 4 } & P2 & 0,756 & Reliabel \\
\cline { 2 - 4 } & P3 & 0,781 & Reliabel \\
\cline { 2 - 4 } & P4 & 0,770 & Reliabel \\
\cline { 2 - 4 } & P5 & 0,762 & Reliabel \\
\hline \multirow{7}{*}{ Cost-Benefit } & CB1 & 0,756 & Reliabel \\
\cline { 2 - 4 } & CB2 & 0,764 & Reliabel \\
\hline Tanggungjawab & TJW1 & 0,779 & Reliabel \\
\cline { 2 - 4 } & TJW2 & 0,768 & Reliabel \\
\hline
\end{tabular}

Sumber: Data primer, diolah (2013). 
Hasil uji reliabilitas, menunjukkan bahwa semua item handal dan reliabel. Hal ini ditunjukkan oleh nilai Cronbach alpha $>60$.

\section{Uji Normalitas}

Tabel 3

Hasil Uji Normalitas Data

\begin{tabular}{|c|c|}
\hline & Etika Penyusunan Laporan Keuangan Syari'ah \\
\hline Kolmogorov-Smirnov $Z$ & 1,461 \\
\hline Asymp. Sig. (2-tailed) & 0,028 \\
\hline
\end{tabular}

Sumber: Data primer, diolah (2013).

Berdasar hasil pengujian dalam tabel 3, menunjukkan bahwa nilai koefisien signifikan sebesar 0,028 $<0,05$ (alpha) maka dapat disimpulkan bahwa data tersebut berdistribusi tidak normal da uji hipotesis diuji dengan Mann-Whitney.

\section{Uji Hipotesis}

\section{a) Hipotesis 1}

Tabel 4

Uji Hipotesis 1

\begin{tabular}{|l|r|}
\hline & Manajemen Laba \\
\hline Mann-Whitney U & 597.000 \\
Wilcoxon W & 2427.000 \\
Z & -6.662 \\
Asymp. Sig. (2-tailed) & .000 \\
\hline
\end{tabular}

Sumber: Data primer, diolah (2013).

Hasil uji hipotesis 1 pada tabel 4 menunjukkan bahwa hipotesis pertama dapat diterima. Artinya mahasiswa akuntansi di Perguruan Tinggi Swasta Islam lebih tidak menyetujui adanya manajemen laba dibandingkan mahasiswa akuntansi di Perguruan Tinggi Umum. Hal ini dikarenakan adanya perbedaan kurikulum, prinsip (acuan), dan teknik mengajar di Perguruan Tinggi tersebut. Mahasiswa akuntansi di Perguruan Tinggi Swasta Islam memiliki pandangan bahwa laba itu memang harus diprioritaskan tetapi bukan berarti harus melakukan berbagai cara untuk membuatnya terlihat baik. 


\section{b) Hipotesis 2}

Tabel 5

Uji Hipotesis 2

\begin{tabular}{|l|r|}
\hline & Salah Saji Laporan Keuangan \\
\hline Mann-Whitney U & 702.000 \\
Wilcoxon W & 2532.000 \\
Z & -5.847 \\
Asymp. Sig. (2-tailed) & .000 \\
\hline
\end{tabular}

Sumber: Data primer, diolah (2013)

Hasil uji hipotesis 2 pada tabel 5 menunjukkan bahwa hipotesis kedua dapat diterima. Artinya bahwa mahasiswa akuntansi di Perguruan Tinggi Swasta Islam memiliki kecenderungan yang lebih rendah untuk melakukan salah saji pada laporan keuangan syari'ah dibandingkan mahasiswa akuntansi di Perguruan Tinggi Umum. Hal ini juga dikarenakan adanya perbedaan kurikulum, prinsip (acuan), dan teknik mengajar.

\section{c) Hipotesis 3}

Tabel 6

Uji Hipotesis 3

\begin{tabular}{|l|r|}
\hline & \multicolumn{1}{|c|}{ Pengungkapan } \\
\hline Mann-Whitney U & 1484.000 \\
Wilcoxon W & 3314.000 \\
Z & -1.675 \\
Asymp. Sig. (2-tailed) & .094 \\
\hline
\end{tabular}

Sumber: Data primer, diolah (2013).

Hasil uji hipotesis 3 pada tabel 6 menunjukkan bahwa hipotesis ketiga ditolak. Pengungkapan informasi dalam perusahaan, mahasiswa akuntansi di Perguruan Tinggi Swasta Islam dan mahasiswa akuntansi di Perguruan Tinggi Umum terbukti bahwa tidak ada perbedaan persepsi dan menganggap pengungkapan itu adalah suatu hal yang penting dalam penyusunan laporan keuangan. 


\section{d) Hipotesis 4}

Tabel 7

Uji Hipotesis 4

\begin{tabular}{|l|r|}
\hline & \multicolumn{1}{|c|}{ Cost-Benefit } \\
\hline Mann-Whitney U & 1264.000 \\
Wilcoxon W & 3094.000 \\
Z & -2.920 \\
Asymp. Sig. (2-tailed) & .004 \\
\hline
\end{tabular}

Sumber: Data primer, diolah (2013).

Hasil uji hipotesis 4 pada tabel 7 menunjukkan bahwa hipotesis keempat dapat diterima. Hal ini berarti kurikulum pada Perguruan Tinggi Umum memberikan penekanan pada benefit dari pengungkapan yang dilakukan perusahaan, sehingga mahasiswa cenderung memandang dari sisi banyaknya aturan-aturan akuntansi yang harus mereka pahami saja. Perguruan Tinggi Swasta Islam lebih memandang aturan-aturan tersebut adalah suatu keharusan yang harus diikuti dan dipatuhi.

\section{e) Hipotesis 5}

\section{Tabel 8}

\section{Uji Hipotesis 5}

\begin{tabular}{|l|r|}
\hline & Tanggung Jawab \\
\hline Mann-Whitney U & 1258.500 \\
Wilcoxon W & 3088.500 \\
Z & -3.035 \\
Asymp. Sig. (2-tailed) & .002 \\
\hline
\end{tabular}

Sumber: Data primer, diolah (2013).

Hasil uji hipotesis 5 pada tabel 8 menunjukkan bahwa hipotesis kelima dapat diterima. Artinya mahasiswa akuntansi di Perguruan Tinggi Swasta Islam memiliki tanggung jawab yang lebih tinggi dalam penyajian laporan keuangan dibandingkan dengan mahasiswa akuntansi di Perguruan Tinggi Umum. Hal ini dikarenakan mahasiswa akuntansi di Perguruan Tinggi Swasta Islam memandang tanggungjawab itu pertanggungjawabannya bukan hanya pada manusia tetapi juga kepada Allah SWT, sedangkan mahasiswa akuntansi di Perguruan Tinggi Umum 
lebih memandang tinggi profesi akuntan daripada suatu kewajiban yang menjadi tanggungjawabnya.

\section{SIMPULAN, KETERBATASAN, DAN SARAN}

Berdasar hasil analisis data mengenai persepsi mahasiswa akuntansi terhadap etika penyusunan laporan keuangan syari'ah sesuai PSAK Nomor 101, maka dari penelitian ini dapat diambil kesimpulan sebagai berikut:

1. Hipotesis 1 dapat diterima, yaitu terdapat perbedaan persepsi mengenai manajemen laba antara mahasiswa akuntansi di Perguruan Tinggi Swasta Islam dan Perguruan Tinggi Umum.

2. Hipotesis 2 dapat diterima, yaitu terdapat perbedaan persepsi mengenai salah saji dalam laporan keuangan dalam perusahaan antara mahasiswa akuntansi di Perguruan Tinggi Swasta Islam dan Perguruan Tinggi Umum.

3. Hipotesis 3 ditolak, yaitu tidak terdapat perbedaan persepsi mengenai pengungkapan informasi yang sensitif dalam perusahaan antara mahasiswa akuntansi di Perguruan Tinggi Swasta Islam dan Perguruan Tinggi Umum.

4. Hipotesis 4 dapat diterima, yaitu terdapat perbedaan persepsi mengenai costbenefit pengungkapan informasi antara mahasiswa akuntansi di Perguruan Tinggi Swasta Islam dan Perguruan Tinggi Umum.

5. Hipotesis 5 dapat diterima, yaitu terdapat perbedaan persepsi mengenai tanggungjawab terhadap pengguna laporan keuangan syari'ah antara mahasiswa akuntansi di Perguruan Tinggi Swasta Islam dan Perguruan Tinggi Umum.

Berdasar pengalaman yang telah dilalui penulis selama melakukan penelitian ini, maka ada beberapa keterbatasan dalam penelitian ini yaitu sebagai berikut:

1. Cara pengumpulan data ini dilakukan peneliti dengan menyebar kuesioner kepada responden di lapangan atau di luar kelas, sehingga bisa saja responden menjawab pertanyaan dengan sekedarnya saja tanpa benar-benar memperhatikan pertanyaan yang ada.

2. Penelitian ini dilakukan dengan survei secara tertulis, sehingga tidak terlepas kemungkinan adanya responden yang kurang memahami pertanyaan-pertanyaan yang diajukan. 
Berdasar keterbatasan yang ada dalam penelitian ini, maka penulis memberikan saran untuk penelitian selanjutnya yaitu:

1. Diharapkan untuk penelitian selanjutnya agar melakukan pengumpulan datanya di dalam kelas sehingga responden benar-benar menjawab setiap pertanyaan sesuai dengan apa yang diketahui.

2. Diharapkan untuk penelitian selanjutnya agar melakukan penelitian dengan survei secara lisan (interview).

\section{DAFTAR PUSTAKA}

Astri, Arfani NK, dan Noer Sasongko. 2005. “Analisis Perbedaan Pengaturan Laba (earning management) pada Kondisi Laba dan Rugi pada Perusahaan Manufaktur di Indonesia”. Jurnal Akuntansi dan Keuangan (April), Vol. 4, No. 1.

Fitriani, Bayu Hardianthi. 2010. "Persepsi Dosen dan Mahasiswa Akuntansi terhadap Etika Penyusunan Laporan Keuangan”. Universitas Pembangunan Nasional "Veteran": Jakarta.

Ghozali, Imam. 2006. Aplikasi Analisis Multivariate dengan Program SPSS. Semarang: Badan Penerbit Universitas Diponegoro.

Harahap. 2001. Kritik Terhadap PSAK Perbankan Syari'ah, Media Riset Akuntansi, Auditing dan Informasi, Vol 1, No. 3.

Herawaty, Arleen, dan Yulius Kurnia Susanto. 2009. "Pengaruh Profesionalisme, Pengetahuan Mendeteksi Kekeliruan, dan Etika Profesi Terhadap Pertimbangan Tingkat Materialitas Akuntan Publik". Jurnal Akuntansi dan Keuangan (Mei), Vol. 11, No. 1.

Hidayat, Imam. P. 2002, Kumpulan Artikel Akuntansi Syari'ah [Online]. Didapatkan: file:///E:/kumpulan artikel akuntansi syari'ah/tujuan-laporankeuangan-akuntansi.html. [8 Oktober 2012].

Ikatan Akuntan Indonesia. 2001. Pernyataan Standar Akuntansi Keuangan No. 101: Akuntansi Perbankan Syari'ah. Jakarta: Salemba Empat.

Indriantoro, Nur dan Bambang Supomo. 1998. Metodologi Penelitian Bisnis untuk Akuntansi dan Manajemen. Edisi Pertama. Yogyakarta: BPFE. UGM. 
Kurniawati, Indah. 2006. Mengolah Data Statistik Dengan SPSS 11.5. Badan Penerbit Universitas Ahmad Dahlan: Yogyakarta.

Mahmud, Amir. 2008. "Persepsi Mahasiswa Akuntansi Mengenai Etika Penyusunan Laporan Keuangan” Jurnal Akuntansi (Desember), Vol. 37, No. 2.

Mulyadi, 2002. Auditing. Edisi 6. Jakarta: Salemba Empat.

Murtanto dan Marini. 2003. "Persepsi Akuntan Pria dan Akuntan Wanita serta Mahasiswa dan Mahasiswi terhadap Etika Bisnis dan Etika Profesi. Simponsium Nasional Akuntansi (SNA) VI. Surabaya: 16-17 Oktober.

Nurlan, Andi Besse. 2011. "Persepsi Akuntan dan Mahasiswa Jurusan Akuntansi terhadap Kode Etik Ikatan Akuntansi Indonesia”. Skripsi. Universitas Hasanuddin: Makassar.

Sarwono, Jonathan. 2012. Metode Riset Skripsi Pendekatan Kuantitatif (Menggunakan Prosedur SPSS). Jakarta: PT. Elex Media Komputindo.

Triyuwono, Iwan, dan Moh As'udi. 2001. Akuntansi Syari'ah: Memformulasikan Konsep Laba dalam Konteks Metafora Zakat. Jakarta: Salemba Empat.

Triyuwono, Iwan. 2003. Sinergi Oposisi Biner: Formulasi Tujuan Dasar Laporan Keuangan Akuntansi Syari'ah. Journal of Islamic Economics Vol. 4, No. 1.

Yulianti dan Fitriany. 2005. "Persepsi Mahasiswa Akuntansi terhadap Etika Penyusunan Laporan Keuangan”. Simponsium Nasional Akuntansi (SNA) VIII. 